Szczęśniak Angelika, Serwin Natalia, Cecerska-Heryć Ela, Stangret Anna, Mularczyk Agata, Grzeszczak Konrad, Topczewska Katarzyna. Analysis of evidence in forensic medicine. Validation of the test method as a tool to control parameters determining the reliability of the analysis results. Journal of Education, Health and Sport. 2020;10(8):174-179. eISSN 2391-8306. DOI http://dx.doi.org/10.12775/JEHS.2020.10.08.020

https://apcz.umk.pl/czasopisma/index.php/JEHS/article/view/JEHS.2020.10.08.020

https://zenodo.org/record/3977491

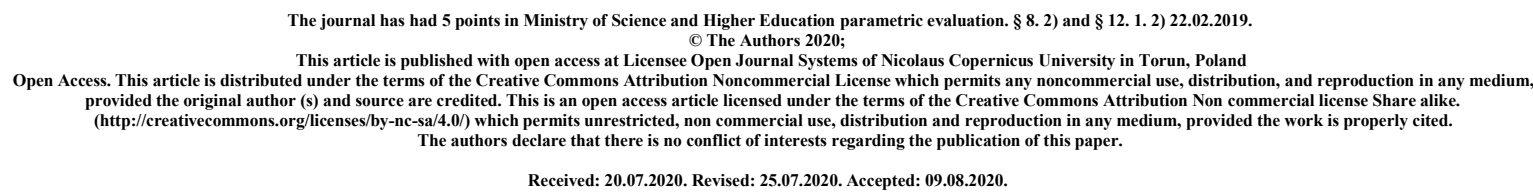

Received: 20.07.2020. Revised: 25.07.2020. Accepted: 09.08.2020.

\title{
Analysis of evidence in forensic medicine. Validation of the test method as a tool to control parameters determining the reliability of the analysis results
}

\author{
Angelika Szczęśniak ${ }^{1, a}$, Natalia Serwin ${ }^{1, b}$, Ela Cecerska-Heryćc ${ }^{1, g}$, Anna Stangret ${ }^{2, c}$, \\ Agata Mularczyk $^{3, d}$, Konrad Grzeszczak ${ }^{4, e}$, Katarzyna Topczewska ${ }^{5, f}$
}

\footnotetext{
${ }^{1}$ Department of Laboratory Medicine, Pomeranian Medical University, Poland

${ }^{2}$ Department of Human and Clinical Anatomy, Pomeranian Medical University, Poland

${ }^{3}$ Department of Obstetrics and Pathology of Pregnancy, Pomeranian Medical University, Poland

${ }^{4}$ Department of Biology and Medical Parasitology, Pomeranian Medical University, Poland

${ }^{5}$ Department of Epidemiology and Management, Pomeranian Medical University, Poland
}

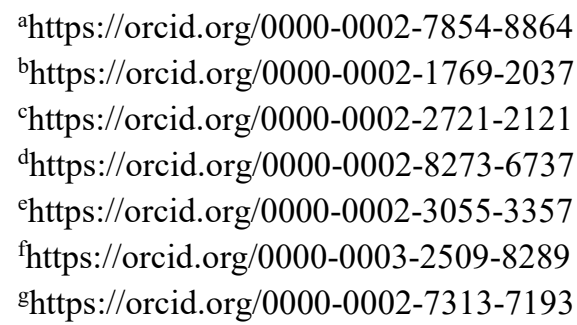




\begin{abstract}
Currently, forensic research foundation is comprised of the methods of genetic analysis. The study of DNA polymorphism became a source of highly reliable evidence, which allow the determination of the genetic profile of biological traces containing genetic material of barely a few cells, collected from all possible substrates, and their further comparison with the genetic profile of the victim or suspect. The forensic expertise of such research, supported by relevant statistical calculations is one of the few objective evidence in criminal proceedings.

The process of DNA testing for forensic purposes is composed of several stages and a number of analyzes. After securing suitable test specimen, the isolation of genetic material is performed. For the quantitative and qualitative analysis of the isolate, the Real Time PCR reaction is performed. This is a crucial moment for the study because it is the assessment of the suitability of samples for further testing. The next step is the amplification of DNA fragments with Multiplex PCR technique. Then, as a result of electrophoretic separation of the sequencer we obtain a genetic profile. Thus obtained profiling results are interpreted as well as compared by specialists.

For analysts in the field of forensic medicine it is necessary to obtain clear genetic profiles. Given the often small amount of DNA that can be obtained and the need for unquestionability of the evidence, it is very important to develop a method with high sensitivity, which allows to obtain completely reliable results. In order to ensure the quality of the research, forensic laboratories must apply the standards and guidelines set by international associations, periodically calibrate their testing equipment, keep complete records of the results and, above all, to validate the used methods. In the laboratory, which intends to apply the procedure in question, internal validation must be carried out. The aim of this process is to determine the reliability and limitations of the method. During the test, the results of manufacturers' verification are validated and the level of efficiency of the said procedure within a particular lab is checked.
\end{abstract}

Key words: DNA, forensic, genetic, Real Time PCR, Multiplex PCR, analysis, validation

\title{
DNA as individual identification material
}

Testing the genetic material samples of all our cells is currently the most reliable method of human identification. The discovery of the fact that every human being has a unique DNA code has been attributed to British scientist Alec Jeffreyson since 1985. Already a year later, the first murderers were convicted thanks to a DNA test [1].

The human body consists of various types of tissues, specialized in performing specific functions. All tissues are composed of single cells which, despite their slightly different structure and function, are the source of "the same" DNA molecule. Most human cells contain two types of DNA, which are two separate genomes - the nuclear genome inside the nucleus and the mitochondrial genome.

The mitochondrial genome is used as an identification marker for forensic genetics, which is due to its special characteristics, including its small size, high number of copies and different inheritance compared to nuclear DNA. 
The high sensitivity of the DNA mitochondrial polymorphism analysis methods has made it a method that can be used for biological trace studies that contain small amounts of biological material.

The nuclear genome is the basic identification marker in forensic research. Almost every cell in the human body has a nucleus, and therefore can be a source of DNA.

Furthermore, every cell in a single organism has an identical DNA, so it is possible to compare the DNA of different cells, which are evidence secured on the spot, e.g. the DNA of semen cells with blood or saliva cells taken as reference material.

DNA genetic information is divided into packets called genes, i.e. regions containing information on a distinct inherited characteristic. The physical structure of DNA is characterized by a high orderly degree, which means that each gene and marker has its own specific place - the locus. These places have been located for many genes and markers.

Different variants of the same gene are called alleles. There may be many alleles of the same gene among humans, i.e. a sequence in a specific locus. The DNA of different people is therefore not identical - each person contains a unique molecule of genetic material. Nevertheless, the essential part of the human genome is the same for all humans and is often called conservative DNA.

According to recent research, the human genome contains about 30,000 genes, which is only $3 \%$ of all DNA - it is coding DNA. The remaining $97 \%$ is the so-called non-coding genetic material. It is the fragments of the non-coding DNA that are used in judicial identification tests. This is due to the variability of these DNA sequences, which is significantly higher than in the more conservative coding DNA $[1,2]$.

Genetic variability is the basis for all human genetic identification tests. It is accepted that genetic polymorphism occurs when there are at least two different alleles in a given DNA locus, which are less common in a population with a frequency of at least $1 \%$. There are two basic types of polymorphisms: single nucleotide polymorphism (SNP) and length polymorphism of DNA fragments. The most common are differences in single nucleotide positions forming DNA strands. SNP consists of simple $A \leftrightarrow G, C \leftrightarrow T$ changes, as well as insertions and deletions of single nucleotides. The frequency of such changes in the genome is on average $1 / 1000 \mathrm{pz}$, although according to some sources these changes are much more frequent - 1/300 pz. This type of polymorphism can be observed both within genes and noncoding regions. This type of polymorphism has been and is used for identification studies conducted in the judicial aspect [3].

Approximately half of the human genome consists of different types of repetitive sequences. From the viewpoint of forensic genetics, fragments of DNA sequences that are repeated tandem, one after the other, several or several times, are very important. These repeating, usually four- or five-nucleotide DNA sequences are located in non-coding DNA, called repeating units. Such fragments are often characterized by very high polymorphism, which is based on differences in the number of repeating units that characterize DNA of different people. Such DNA segments are called Variable Number Of Tandem Repeats (VNTR) sequences. VNTR sequences, also known as minisatellite sequences, for which the repetitive sequence had a length of several to several nucleotides, were used in forensic genetics [1]. From the viewpoint of identification studies, the most important type of repeatable sequences are micro satellite sequences - STR (Short Tandem Repeats). 
In the case of this marker, the repeatable unit is very short. In modern forensic genetics, STR systems with a repetitive unit consisting of four pairs of bases are commonly used.

\section{Analysis of evidence in forensic medicine}

The identification of the human genome structure and the creation of analysis methods for its polymorphisms have led to a significant development in many fields, including forensics [4]. DNA polymorphism studies have become a source of highly reliable evidence, allowing to determine the genetic profile of biological traces containing the genetic material of only a few cells, collected from all possible sources, and compare it with the genetic profile of the victim or suspect. Forensic expert opinions from such studies, supported by appropriate statistical calculations, are one of the few objective evidence in court proceedings [1]. Currently, forensic studies use commercial kits containing ready-to-use reagents necessary for both the isolation of genetic material and the preparation of real-time PCR responses. Thanks to this, the number of manual activities is reduced and the risk of errors is minimized [5].

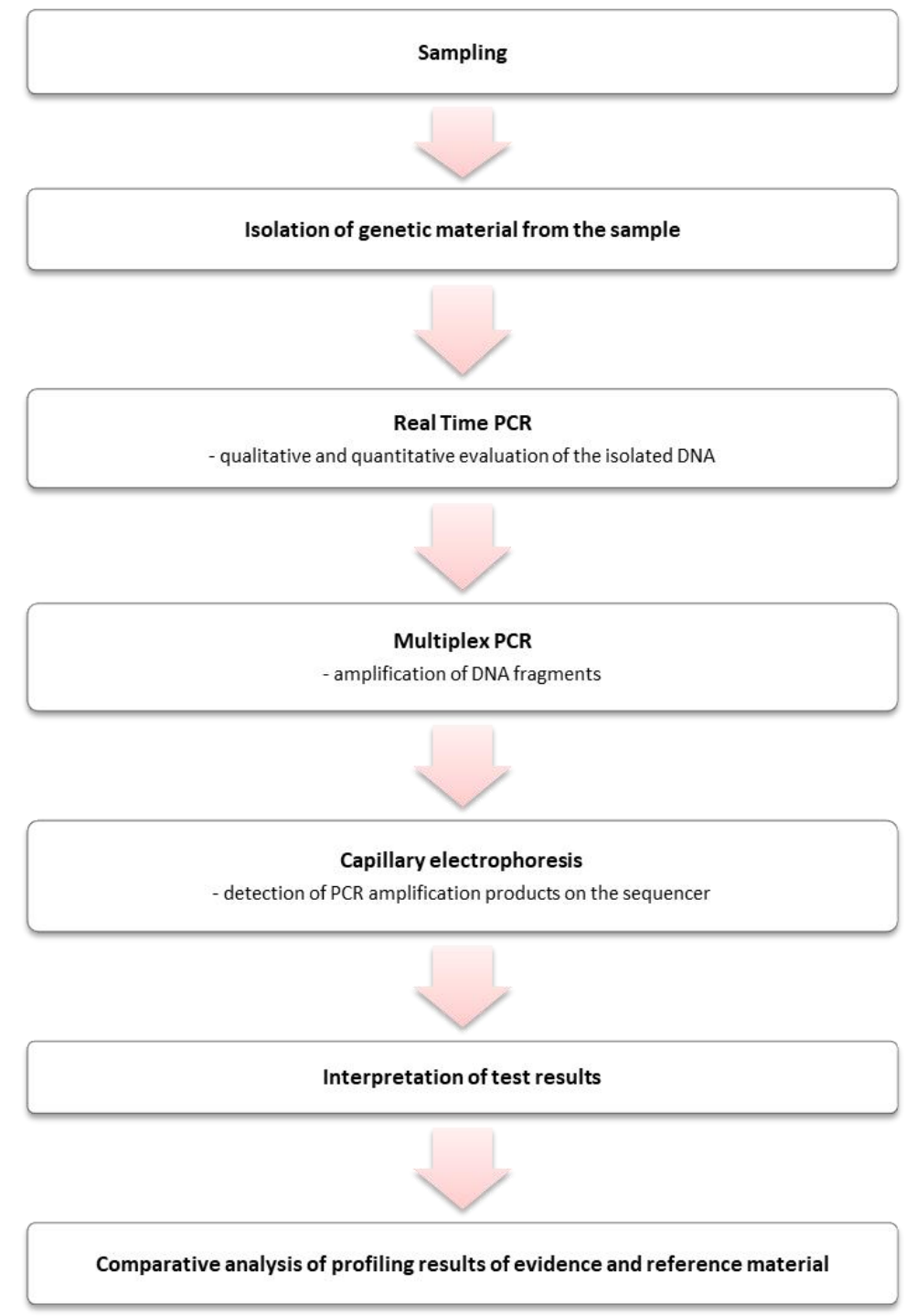

Figure 1. Schematic diagram of the DNA analysis process. 


\section{Validation of the test method as a tool to control parameters determining the reliability of the analysis results}

Biological material, which goes to forensic laboratories, very often has a significant degree of DNA degradation and a high level of contamination. This may result in a small amount of DNA, as well as poor quality. Therefore, taking into account the evidentiary value of DNA profiling, in order to ensure high quality of analysis results, it is extremely important to maintain high standards of research and apply proven principles of conduct. Forensic laboratories must, inter alia, apply standards and guidelines established by international associations, validate the methods used, perform cyclical calibration of testing equipment, and keep complete documentation of results. These elements guarantee multi-level control and optimal functioning of the laboratory.

New, previously unused methods should meet specific legal requirements. According to the current genetic regulations, a diagnostic laboratory is subject to the Act on Laboratory Diagnostics and the requirements of the Regulation of the Minister of Health of 23/03/2006 on quality standards for medical diagnostic and microbiological laboratories $[6,7,8]$. Validation is also a basic requirement to meet the standards described by the International Organization for Standardization in the PN-EN ISO/IEC 17025:2005 standard [9]. Validation is a process in which the procedure is evaluated in order to determine its effectiveness and reliability for analysis on the basis of a number of parameters, including sensitivity, accuracy, specificity and selectivity, precision, linearity, limit of detection (LOD) and limit of quantification (LOQ).

Precision determines the dispersion of results in a series of measurements, i.e. the degree of consistency between single analysis results. This parameter can be expressed as repeatability, defined as the variability of results obtained from multiple tests on the same sample, performed by the same analyst, at short intervals using the same test and measurement instrument, the same reagents and under the same environmental conditions, and reproducibility, which allows the evaluation of method's ability to produce the same results in different laboratories, analysts, reagents and instruments. In most cases, precision is measured by standard deviation (SD), which is defined as the dispersion of the individual determination values around the mean value. When all the results are identical, SD is equal to zero. The value of standard deviation is higher the higher the dispersion of results $[10,11]$. The Real Time PCR method, which we use, also makes it possible to determine limit concentrations. The consequence of too low a concentration of DNA in the sample are mainly stochastic effects - lack of allele balance in the heterozygous locus (significant disproportions in peak heights among sister alleles), drop-out alleles or insertion of another random allele (drop-in) [12]. In the case of too much matrix DNA, there is excessive amplification, which results in disturbances in the background, too many artifact peaks, as well as flattened allele peaks, whose signal is so intense that the vertex significantly exceeds the scale [13]. In practice, the limit of detection (LOD) is determined, defined as the lowest concentration of an analyte in a tested sample that can be detected by a given method. This allows the selection of samples that are suitable for further, often costly, analysis. 


\section{References}

1. Branicki W., Kupiec T., Wolańska-Nowak P., Proces analizy DNA dla celów sądowych, Badanie DNA do celów sądowych, Red. Branicki W., Wydawnictwo Instytutu Ekspertyz Sądowych, Kraków 2008, s. 15-23.

2. Andréasson $\mathrm{H}$, Gyllensten $\mathrm{U}$, Allen $M$. Real-time DNA quantification of nuclear and mitochondrial DNA in forensic analysis, Biotechniques, 08/2002, 33(2):402-4, 407-11.

3. Żaba C., Wybrane zagadnienia $\mathrm{z}$ medycyny sądowej, Wydawnictwo Naukowe Uniwersytetu Medycznego im. Karola Marcinkowskiego w Poznaniu, Poznań 2014, s. 73-95.

4. Schiffner L. A., Bajda E. J., Prinz M., Sebestyen J., Shaler R., Caragine T. A.: Optimalization of a simple, automatable extraction method of recover sufficient DNA from low copy number DNA samples for generation of short tandem repeats profile. Croat, M J. 2005, 46: 578-586.

5. Ferguson E., Effects of $\mathrm{pH}$ on Binding of DNA Using the PrepFiler BTA Forensic DNA Extraction Kit on the AutoMate Express Forensic DNA Extraction System, Master of Science, 05/2014, 1-9.

6. Ciesielska A., Sikorski M., Zastosowanie techniki PCR w czasie rzeczywistym do walidacji eksperymentu mikromacierzowego, Instytut Chemii Bioorganicznej, Polska Akademia Nauk, Poznań 2008.

7. Łaczmański Ł., Łaczmańska I., Walidacja metod molekularnych przeznaczonych do laboratoryjnej diagnostyki genetycznej, Katedra i Klinika Endokrynologii, Diabetologii i Leczenia Izotopami, Katedra i Zakład Genetyki, Akademia Medyczna we Wrocławiu, 2009.

8. Tysarowski A., Fabisiewicz A., Kolasa I., Kupryjańczyk J., Ścieglińska D., Rusin M., Krawczyk Z., Woźniak A., Morzuch L., Limon J., Kowalczuk O., Chyczewski L., Wójcik P., Stachura J., Wieruszewska-Kowalczyk K., Pokrzepa M., Olszewski W., Nowacki M., Siedlecki J., Walidacja wybranych technik molekularnych oznaczania mutacji w kodonie 12 i 13 genu K-RAS przeprowadzona w pięciu ośrodkach badawczo-naukowych Polski, Onkologia w Praktyce Klinicznej, 2008.

9. Ragsdale R., Internal Validation, Florida Department of Law Enforcement (FDLE), 08/2005 at NFSTC.

10. Spólnicka M., Zbieć - Piekarska R. Proces walidacji w kryminalistycznych badaniach profilowania DNA. Problemy Kryminalistyki. 2008, 262, 5-13.

11. Spólnicka M., Zbieć-Piekarska R., Wewnętrzna walidacja metody kwantyfikacji DNA z wykorzystaniem zestawu Quantifiler ${ }^{\circledR}$ Human DNA Quantification Kit i aparatu 7500 Real-Time PCR System wraz z oprogramowaniem Hid Real-Time PCR Analysis Software V 1.1 w Zakładzie Biologii Centralnego Laboratorium Kryminalistycznego Policji, Problemy Kryminalistyki, 2014.

12. Dąbrowska J., Makowska Ż., Spólnicka M, Szabłowska-Gnap E., Najczęstsze zjawiska występujące podczas analizy profili DNA w multipleksowych systemach STR, Problemy Kryminalistyki, 2013.

13. Green RL, Roinestad IC, Boland C, Hennessy LK. Developmental validation of the quantifiler real-time PCR kits for the quantification of human nuclear DNA samples, J Forensic Sci, 07/2005, 50(4):809-25. 